\title{
Dear Stevie
}

\section{Tara Mokbtari}

For Stevie Smith, the subject of my PhD, who slit her wrists at work on July 1 st 1953 and lived to write more death poems than any other poet I know.

I know how you felt

That Wednesday at work

When you wanted out

So badly

You tried to cut your way

With a knife behind your secretarial desk

And all the blood screamed out of you

And they took you away

Said you're a nervous wreck

And anemic too

And they kept an eye on you

And you wrote your friend Kay

A jovial note to say

Work would be a thing of the past

The doctors gave you leave for life

And you took it.

I feel that way every Wednesday

And every Thursday, for that matter

I want out

So badly

When I stand and look at classrooms full of dull eyes,

Laptops and mobile phones 
(Those awful kinds of portable computers

You'd hate them if you saw them)

Teaching greedy, materialist

Crude ideas of an industry designed

To sell cigarettes to children

And shit all over the television ...

I want to take a knife

And make the long incision

And show them

How dark red a poet's blood can be

How thick and fast it spills

How death is one truth

Those bastards can never spin

(No matter how good they get).

I want someone to take me away

Say it's ok, I don't ever have to go back

Not just because I couldn't hack it

But because it's inhumane

To make a poet pimp her brain and body

(I cry constantly and

the sciatica's a pain in the ass)

For such debase banality.

I got my certificate in the mail,

I'm a doctor now too,

In fact, I'm a doctor of you.

I can't look at it though,

It makes me ill

I get chills thinking how

It should have been the last thing I ever did

I should have left it at that

The Wednesday in July when I

Packaged up all your deaths

And submitted them to be judged

Knowing full well all your deaths

Were perfect,

And only one of mine

Could ever be. 